\title{
XIII. On the apparent viscosity of ice
}

\section{G.S. Turpin \& A.W. Warrington B.Sc.}

To cite this article: G.S. Turpin \& A.W. Warrington B.Sc. (1884) XIII. On the apparent viscosity of ice , Philosophical Magazine Series 5, 18:111, 120-123, DOI: $10.1080 / 14786448408627575$

To link to this article: http://dx.doi.org/10.1080/14786448408627575

\section{曲 Published online: 29 Apr 2009.}

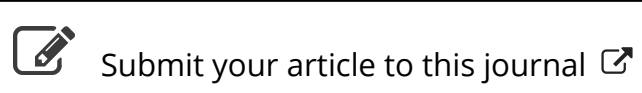

\footnotetext{
Џll Article views: 2
}

Q View related articles $\square$

Citing articles: 2 View citing articles 5 
nitre in water at $125^{\circ}$. Their experiments on solubility appear to stop short far below the temperature of fusion of the salt per se (excepting in cases where the salt contains water of crystallization). They distinctly state, however, that infinite solubility is "nearly true of benzoic acid, which melts at $120^{\circ} \ldots \ldots$ By sealing it up with water in a glass tube and heating to a few degrees beyond the melting-point, intermixture occurs in all proportions; and the liquid so obtained, on cooling to $120^{\circ}$, or about $1^{\circ}$ lower, becomes turbid from deposition of oily drops, which, however, immediately crystallize." -F. G.]

XIII. On the Apparent Viscosity of Ice. By G. S. Turpin and A. W. Warrington, B.Sc., Students in the Ovens College, Manchester*

GOME years ago Mr. J. T. Bottomleyt devised an experi$D$ ment to illustrate the effect of pressure on a melting block of ice. A stout copper wire with heavy weights attached at its two ends is slung across a block of ice which is supported in any convenient manner. The wire gradually makes its way through the block; but the ice constantly re-forms behind the wire, so that after the block has been cut right through it is still whole and entire. The path travelled over by the wire does not, however, possess its original structure, but is now semi-transparent, and the block splits readily along this path.

Bottomley found that string, under the same circumstances as the copper wire, would not cut through ice. The explanation he gives is that "the string is not a good enough conductor to relieve itself of the cold in front and pass it back to the water behind." In this shape the explanation does not seem very clear, but in the following expanded form it is evident enough. When the wire starts its journey, its upper surface is in contact with ice-cold water, and its lower surface in contact with ice. The pressure of the wire tends to make the ice beneath it melt; but before this can occur the latent heat of liquefaction must be supplied, and in the case of the copper wire is readily obtained from the water above, which is in consequence frozen. The newly formed water is forced upwards round the wire; and the same process is repeated until the wire has made its way through the block. When,

* Communicated by the Authors.

+' 'Nature' vol. v. 1872 , p. 185. 
however, string is used instead of copper wire, this conduction of heat does not readily occur.

In repeating this experiment, water could be distinctly seen moving quickly round the sides of the wire from its under to its upper surface; and in one particular case, when a brass wire one tenth of an inch in diameter was used with two weights of $56 \mathrm{lb}$, each, crystals of ice were seen actually growing in the water on the upper surface of the wire, just before it became completely buried in the ice.

In order to determine the effect of conductivity an experiment was made with five different wires. As a matter of convenience, each wire was placed on a separate block of ice, but the blocks were sawn to as nearly as possible the same size. The times taken by the different wires in cutting through the blocks were:-

\begin{tabular}{|c|c|c|}
\hline Wire. & Time, in minutes. & Conductivity. \\
\hline Silver .... & 192 & 100 \\
\hline Copper & 184 & $73 \cdot 6$ \\
\hline Brass ......... & 267 & $23 \cdot 6$ \\
\hline Iron .... & 300 & 11.9 \\
\hline German-silrer .. & 314 & $6 \cdot 3$ \\
\hline
\end{tabular}

Each wire was $\cdot 67$ millim. diameter, and carried $2 \frac{1}{2} \mathrm{lb}$. The numbers obtained show that the time taken increases as the conductivity decreases; but there is an apparent exception in the case of the silver and copper wires. To find whether this was due to any difference in the blocks of ice, they were interchanged, with the following result:-

\begin{tabular}{|c|c|c|}
\hline Wire. & Time, in minutes. & Conductivity. \\
\hline Silver .............. & 103 & 100 \\
Copper ............ & 110 & 73.6 \\
\hline
\end{tabular}

In this case the silver has the advantage; and the difference in the times, in proportion to the total time taken, is greater than before.

Another experiment was made with the same two wires on one block, each wire being weighted with $20 \mathrm{lb}$. Results:- 
On the Apparent Viscosity of Ice.

\begin{tabular}{|c|c|c|}
\hline Wire. & Time, in minutes. & Conductivity. \\
\hline Silver............... & $13 \frac{\mathrm{t}}{2}$ & 100 \\
Copper ............ & $15 \frac{1}{2}$ & 73.6 \\
\hline
\end{tabular}

The difference is here one eighth of the whole time, and is again in favour of the silver wire.

These results prove that the time increases as the conductivity decreases; but we have been unable to find any simple relation connecting them together.

Another experiment was made to determine the influence of the weight used. Three pieces of iron wire, cut from the same sample, were loaded with different weights and placed across a block of ice. The times taken in cutting through were as follows:-

\begin{tabular}{|c|c|c|}
\hline Load. & Time, in minutes. & Load $\times$ Time. \\
\hline $5 \mathrm{lb}$. & 225 & 1125 \\
$7 \frac{1}{2} \mathrm{lb}$. & $146 \frac{1}{2}$ & 1099 \\
$12 \frac{1}{2} \mathrm{lb}$. & 84 & 1090 \\
\hline
\end{tabular}

The numbers in the third column show that the time taken is approximately inversely proportional to the load.

Amongst the experiments made by Pfaff * to prove the plasticity of ice is the following one :-An iron tube placed upright on a block of ice is completely surrounded with snow to provent its temperature rising above $0^{\circ} \mathrm{C}$., and a pressure of about two atmospheres is applied at its upper end by means of a one-armed lever: the tube slowly forced its way into the ice, and after an hour had sunk 3 centim. At the close of the experiment $P$ faff found inside the iron tube a cylinder of ice, which fitted so elosely that it would not fall out by its own weight. From this Pfaff concludes that the sinking of the iron tube is due almost entirely to the plasticity of ice, and only minutely, if at all, to the effect of pressure in lowering the freezing-point of water.

It is, however, at once evident that the explanation given of Bottomley's experiment also applies to this; the only difference being that, whereas in the former case the heat necessary for the liquefaction of the ice under presure is obtained from

* Pogg. Ann. clv. p. 169 (1875). 
the water above the wire, in this it is obtained from the water which is about the sides of the tube. The existence of the tightly fitting cylinder of ice inside the tube, so far from being an objection to this explanation, is a necessary consequence of it.

In order to confirm this explanation, Pfaff's experiment was repeated with four pieces of tubing-of glass, copper, brass, and lead, each about 1 foot long and 3 inch bore. The distances to which the tubes penetrated in four hours are contained in the following table:-

\begin{tabular}{|c|c|c|}
\hline Tube. & Load. & Distance. \\
\hline Copper ........... & $2 \mathrm{lb}$. & 100 millim. \\
Brass ............. & 2, & $35 "$ \\
Lead ............. & 2, & $7 "$, \\
Glass ............. & $2 \frac{1}{2}$, & $3 "$, \\
\hline
\end{tabular}

The glass tube was loaded with an extra half-pound in order to make up for its smaller weight.

This shows conclusively that when the experiment is made at a temperature not lower than $0^{\circ} \mathrm{C}$., the chief factor is the lowering of the freezing-point by pressure, and not the plasticity of ice. But in the same paper Pfaff describes experiments conducted at temperatures below zero in which the iron tube still penetrated into the ice, though to a very much smaller distance than before. Thus, at a temperature varying from $-4^{\circ}$ to $-1^{\circ}$, the same tube which at $0^{\circ}$ sank 30 millim. in one hour, sank only $1 \frac{1}{4} \mathrm{millim}$. in twelve hours. In this case the experiment seems eapable of explanation only by admitting the presence of a certain degree of plasticity in ice, which is rendered very probable by other experiments described by Pfaff, where a sheet of ice bends gradually under its own weight.

XIV. On the Thermal Relationship between Water and certain Salts. By B. IllingworTh and A. Howard*.

THE study of the relationship towards water of certain 1 organic salts belonging to one and the same series promised to throw light upon the general question of the relationship between salts and water, inasmuch as the degree of difference between the members compared may be made at will very

* Communicated by the Physical Society. Read June 14, 1884. 